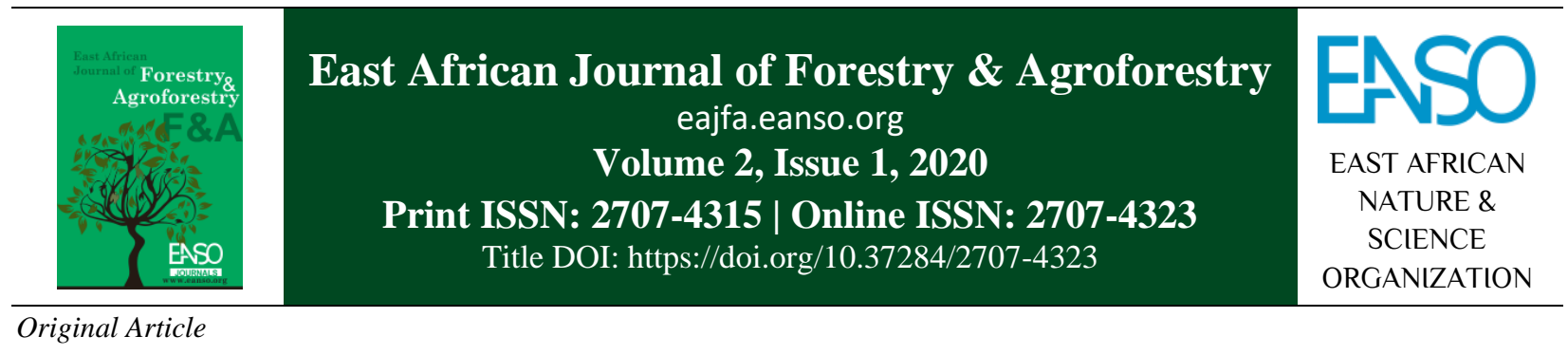

\title{
Socio-economic Factors Affecting Adoption of Agroforestry Practices in Forest Adjacent Communities: The Case of Ndabibi Location, Nakuru County, Kenya
}

\section{Caxton Gitonga Kaua ${ }^{{ }^{*}}$}

${ }^{1}$ Wangari Maathai Institute of Peace and Environment Studies.

* Author for correspondence email: Caxtonk2008@gmail.com ORCID: https://orcid.org/0000-0003-4231-9127

Article DOI: https://doi.org/10.37284/eajfa.2.1.143

\section{Date Published: ABSTRACT}

27 Apr 2020 Agroforestry greatly helps to improve production by creating the right conditions for other components of the production system and also creates other

Keywords: income streams and benefits. Agroforestry also creates an alternative source of forest derived products and thus help reduce forest destruction. The

Agroforestry Practice, Agroforestry Adoption, Socio-Economic Factors, Specific Local Context,

Forest Adjacent Community, development of agroforestry in Africa has not been very successful due to poor understanding of the underlying socio-economic factors underpinning the adoption in specific local contexts, including adjacent forest communities. This hinders proper decision making hence ineffective management of agroforestry practices. This is especially the case for Ndabibi Location an area marked by low farm production including degradation of the adjacent Eburru Forest. This study, therefore, aimed to analyze the socio-economic factors affecting agroforestry adoption in Ndabibi Location, a forest adjacent community. This study used a descriptive study design and systematic sampling design. The study used primary and secondary data where primary data was collected using a household questionnaire survey, focus group discussions, key informant interviews and observations. The study found socio-economic factors either have positive or negative relationships with agroforestry adoption. The factors that have a positive relationship with agroforestry practice include age, household size, formal education level, contact with extension services, membership to community-based associations and income levels. Gender, land size and forest dependency were found to have a negative relationship with the adoption of agroforestry practice. Understanding of the socio-economic factors underlying and thus affecting adoption of agroforestry adoption in Ndabibi Location will help communities, policymakers and practitioners to make the 
right planning and management decisions towards the promotion of agroforestry practice in forest adjacent communities. This shall increase the production, livelihoods and income sources diversification hence leading to the sustainable management of forest ecosystems.

\section{APA CITATION}

Kaua, C. (2020). Socio-economic Factors Affecting Adoption of Agroforestry Practices in Forest Adjacent Communities: The Case of Ndabibi Location, Nakuru County, Kenya. East African Journal of Forestry and Agroforestry, 2(1), 59-67. https://doi.org/10.37284/eajfa.2.1.143

\section{CHICAGO CITATION}

Kaua, Caxton. 2020. "Socio-Economic Factors Affecting Adoption of Agroforestry Practices in Forest Adjacent Communities: The Case of Ndabibi Location, Nakuru County, Kenya”. East African Journal of Forestry and Agroforestry 2 (1), $59-67$. https://doi.org/10.37284/eajfa.2.1.143.

\section{HARVARD CITATION}

Kaua, C. (2020) "Socio-economic Factors Affecting Adoption of Agroforestry Practices in Forest Adjacent Communities: The Case of Ndabibi Location, Nakuru County, Kenya", East African Journal of Forestry and Agroforestry, 2(1), pp. 59-67. doi: 10.37284/eajfa.2.1.143.

\section{IEEE CITATION}

C. Kaua, "Socio-economic Factors Affecting Adoption of Agroforestry Practices in Forest Adjacent Communities: The Case of Ndabibi Location, Nakuru County, Kenya”, EAJFA, vol. 2, no. 1, pp. 59-67, Apr. 2020.

\section{MLA CITATION}

Kaua, Caxton. "Socio-Economic Factors Affecting Adoption of Agroforestry Practices in Forest Adjacent Communities: The Case of Ndabibi Location, Nakuru County, Kenya". East African Journal of Forestry and Agroforestry, Vol. 2, no. 1, Apr. 2020, pp. 59-67, doi:10.37284/eajfa.2.1.143.

\section{INTRODUCTION}

Agroforestry is the practice of deliberately growing trees integrated with other components including livestock and crops on the same landscape (Sanchez, 1995). The practice of agroforestry has a long history. Early farmers integrated trees into farming systems to support agricultural with the ultimate aim of enhancing food production. However, by the end of the $19^{\text {th }}$ century, the ultimate objective of agroforestry had shifted towards the establishment of plantations. Modern agroforestry started in 1971 based on the premise that associations of crops, trees and livestock could contribute significantly to and simultaneously optimize both agricultural and forestry production (Schroeder, 1999). Based on this premise, the practice of agroforestry, therefore, employs various systems based on the combination of several components (Nair, 1989). These systems include agrosilviculture, pastoralsilviculture and agropastoralsilviculture, including other more specialized systems such as aquasilviculture, serisilviculture and apisilviculture (WCFSD,
1999). ICRAF (1994) classifies agroforestry based on the temporal occurrence of components including sequential and simultaneous.

The practice of agroforestry has many benefits given the many components involved. These systems contribute towards soil and water conservation, carbon sequestration, improve crop and livestock production, help improve food and nutritional security and play a major role to household's income generation in rural areas among other benefits (Cunningham and Saigo, 1992; Kang et al., 1995; Kwesinga and Ajayi, 1995; Huang et al., 2002; Montagnini and Nair, 2004; Batjes, 2005). Agroforestry also provides an alternative source of forest derived products, reducing forest encroachment, degradation and deforestation (KEFRI, 2010; Anderson, 1990; Angelson \& Komiwitze, 2001; Raiford, 1987).

Despite these benefits, the adoption of agroforestry practice especially in Africa has not been very successful. Agroforestry initiatives have been marked by low levels of adoption and failure after adoption (Patanayaket et al., 2003; Mercer and Miller, 1998; Nkamleu and Manyong, 2005). This 
has mainly been caused by a significant lack of adequate information hence poor understanding of the socio-economic factors underlying adoption and performance of agroforestry practice in specific areas hence reliance on generalized information in decision making. Different areas, however, have different needs, resources and managerial capacities hence livelihood systems. This is as defined by the prevailing socio-economic factors which have profound effects on their decision making on agroforestry practice and production systems. This is more so for adjacent forest communities.

Interactions of the communities with the adjacent forests have an influence on decision-making process especially as appertains to their production systems. These interactions with the forests, therefore, have implications on the community's adoption of agroforestry practice which in turn has an influence on the structure and functions of the forests. These interactions result in unique livelihoods and ecological contexts defined by the prevailing socio-economic factors which in turn influence production systems including agroforestry practice. Accurate information on socio-economic factors influencing agroforestry practice by adjacent forest communities including Ndabibi Location is, however, scanty in quality and quantity. This makes it difficult for policymakers and practitioners to successfully plan and implement proper interventions pertaining to agroforestry practice, management of the adjacent forests and hence livelihoods improvement.

This study, therefore, aimed to analyze the socioeconomic factors affecting the adoption of agroforestry practice in Ndabibi Location. The location lies on the leeward side of Eburru Hills adjacent to Eburru Forest, one of the forest blocks that form the Mau Forest complex in Kenya. The location, therefore, constitutes a forest adjacent community. The area experiences frequent droughts and is often marked by severe food and water insecurity. This is caused by poor land use and production practices which has led to forest encroachment, degradation and deforestation resulting in negative impacts on local livelihoods. This situation can be alleviated through increased adoption of agroforestry practices.

\section{MATERIALS AND METHODS}

\section{Study Area}

Ndabibi Location is located in Maella Ward, Naivasha Subcounty in Nakuru County, Rift valley, Kenya. Ndabibi Location lies adjacent to Eburru Forest block of the Mau Forest complex which borders it to the North. The location borders Lake Naivasha to the South East. It measures 131.72 $\mathrm{KM}^{2}$ (KNBS, 2010). Ndabibi Location has a total population of 8,389 persons comprised of 4,527 males and 3,871 females in 2,361 households with a population growth rate is $3.4 \%$ (KNBS, 2010). Most of the population (74\%) is comprised of youth aged below 30 years which leads to high unemployment rates (G.O.K, 2009). Majority of the households are located with a $2 \mathrm{Km}$ radii of Eburru Forest where there is a high population density compared to the general density for the entire locations area which is 64 persons per $\mathrm{Km}^{2}$. The settlement pattern is highly influenced by the availability of natural resources and the presence of large farms in the lower parts of the location (G.O.K, 2008).

The soils in the area are andosols weathered from the pyroclastic parent material. The soils are volcanic, highly volcanic and loose, thus susceptible to degradation, especially through soil erosion. Ndabibi Location lies in climatic zone IV and receives rainfalls of $700-760 \mathrm{~mm}$ per year. This rainfall has a bimodal pattern with long rains occurring between March and June and short rains from October to November. Temperature ranges between $24{ }^{\circ} \mathrm{C}$ to $29.3{ }^{\circ} \mathrm{C}$ with the highest temperatures experienced during the months of January and February and the lowest temperatures in the months of June and July (GOK, 2008).

Water drainage in the area mainly occurs through underground rivers towards Lake Naivasha. Biodiversity in the area is mainly characterized by the presence by the adjacent Eburru Forest which contains rare species such as the critically endangered mountain bongo. Eburru Forest has thus experienced a $60 \%$ reduction in the Kenya afro tropical highland biome bird species known to have existed in the Mau Forest (NMK, 2009). 
Agriculture is the major land use and economic activity in Ndabibi Location with $80 \%$ of the population depends on agriculture as the main source of income. Local people mainly depend on rain-fed agriculture leading to low production, which is exacerbated by poor agricultural practices and environmental degradation. The main agroforestry systems in the area include agrosilviculture and agrosilvipastoralculture. This is done in various patterns including zoned planting such as zoned sparse and zoned dense either planted using boundary or hedgerow planting. There is mixed planting including mixed sparse and mixed dense.

\section{Data Collection and Analysis}

The study employed a descriptive study design. Sampling was done systematically with respondents being chosen at an interval of every three households. Systematic sampling was chosen given the distribution of the population aligned to the forest boundary. A sample size of 100 respondents was arrived at Nasiurma (2000) formula i.e. $\mathrm{n}=\left(\mathrm{NCv}^{2}\right) /\left(\mathrm{Cv}^{2}+(\mathrm{N}-1)\right.$ e2) where: $\mathrm{N}=$ Population; $\mathrm{Cv}=$ Coefficient of variation (take $0.5)$; e $=$ Tolerance at desired level of confidence (take 0.05 at $95 \%$ confidence level) (KIM, 2009). Data was sourced from secondary and primary sources. Primary data was collected through Focus group discussions, key informant interviews, observation and household's questionnaire survey.

Data analysis was done using descriptive analysis and thematic analysis. Spearman's rank correlation analysis was used to find the relationship between socio-economic factors and adoption of agroforestry practice. Levels of agroforestry adoption were categorized into very low adoption ( $\leq 25$ trees); low adoption (26 - 50 trees); high adoption (26 - 50 trees) and very high adoption (>75 trees).

\section{RESULTS AND DISCUSSIONS}

\section{Socio-economic Characteristics in Ndabibi Location}

The socio-economic characteristics in Ndabibi Location were as shown in Table 1.
Table 1: Description of socio-economic characteristics in Ndabibi Location

\begin{tabular}{|c|c|}
\hline Variable & Characteristics \\
\hline Gender & $\begin{array}{l}\text { Male }=42 \% \\
\text { Female }=58 \%\end{array}$ \\
\hline Age & $\begin{array}{l}\leq 25 \text { years }=4 \% \\
26-35 \text { years }=22 \% \\
36-65 \text { years }=62 \% \\
>65 \text { years }=12 \%\end{array}$ \\
\hline Household size & $\begin{array}{l}\leq 3 \text { persons }=26 \% \\
4-5 \text { persons }=36 \% \\
6-7 \text { persons }=22 \% \\
>7 \text { persons }=165\end{array}$ \\
\hline $\begin{array}{l}\text { Formal education } \\
\text { level }\end{array}$ & $\begin{array}{l}\text { None }=20 \% \\
\text { Primary }=56 \% \\
\text { Secondary }=23 \% \\
\text { Tertiary }=1 \%\end{array}$ \\
\hline $\begin{array}{l}\text { Contact with } \\
\text { extension service }\end{array}$ & $\begin{array}{l}0 \text { contacts }=33 \% \\
1-4 \text { times }=48 \% \\
5-8 \text { times }=8 \% \\
9-12 \text { times }=1 \% \\
>12 \text { times }=10 \% \\
\end{array}$ \\
\hline $\begin{array}{l}\text { Membership to } \\
\text { community based } \\
\text { associations }\end{array}$ & $\begin{array}{l}\text { Don't belong to any } \\
\text { association }=44 \% \\
1 \text { association }=33 \% \\
>1 \text { association }=8 \% \\
\text { Official in an association } \\
=15 \%\end{array}$ \\
\hline Income level & $\begin{array}{l}\text { KShs } \leq 2500=35 \% \\
\text { KShs } 2501-5000= \\
32 \% \\
\text { KSh } 5001-7500=15 \% \\
\text { KSh }>7500=18 \%\end{array}$ \\
\hline Land size & $\begin{array}{l}>0-2.5 \text { acres }=61 \% \\
>2.5-5 \text { acres }=30 \% \\
>5 \text { acres }=9 \%\end{array}$ \\
\hline Land tenure & $\begin{array}{l}\text { Squatter }=16 \% \\
\text { Tenancy }=11 \% \\
\text { Leasehold }=1 \% \\
\text { Freehold }=72 \%\end{array}$ \\
\hline Forest dependency & $\begin{array}{l}\text { Very low }=23 \% \\
\text { Low }=24 \% \\
\text { High }=9 \% \\
\text { Very High }=44 \%\end{array}$ \\
\hline
\end{tabular}




\section{Effect of Socio-economic Factors on the Adoption of Agroforestry Practices}

The effect of socio-economic factors on the adoption of agroforestry practices was assessed by calculating the relationship using Spearman correlation analysis. The results arrived at are as shown in Table 2. The effect of gender on the adoption of agroforestry practice showed a negative Spearman's correlation coefficient of $r=-0.036$, $\mathrm{p}>0.01$ which was not significant indicating that gender is not a significant predictor of adoption of agroforestry practice. Women are more involved in agricultural activities and have intimate relationships with hence knowledge of farmlands and trees. Women also have a private influence on decision making hence public actions undertaken by men in addition to being involved in these processes themselves. Women are more involved in environmental conservation work and thus may adopt agroforestry more. Women in the study area participate more in community-based associations which through which development activities, including training and extension services on agroforestry and related projects are undertaken. They, therefore, have more access to agroforestry knowledge and support hence high adoption. Women also have less access to land which means they have to ensure intense land management practices to boost production which leads to increased adoption of sustainable practices such as agroforestry. Being the key collectors of firewood in the household means they may invest more in agroforestry in order to access the resource. This finding is similar to observations by Fortmann and Rocheleau (1984); Schroeder (1999).

Table 2: Correlation between socio-economic factors and adoption of agroforestry practice

\begin{tabular}{|c|c|c|}
\hline Variable & $\begin{array}{l}\text { Correlation } \\
\text { Coefficient }\end{array}$ & Sig \\
\hline Gender & -.036 & .720 \\
\hline Age & .019 & .848 \\
\hline Household size & .055 & .586 \\
\hline Formal education level & $.222 *$ & .026 \\
\hline $\begin{array}{l}\text { Contact with extension } \\
\text { service }\end{array}$ & $.393 * *$ & .000 \\
\hline $\begin{array}{lr}\begin{array}{l}\text { Membership } \\
\text { community }\end{array} & \text { to } \\
\text { associations } & \text { based }\end{array}$ & $.352 * *$ & .000 \\
\hline
\end{tabular}

\begin{tabular}{lll}
\hline Variable & $\begin{array}{l}\text { Correlation } \\
\text { Coefficient }\end{array}$ & Sig \\
\hline Income level & $.289^{* *}$ & .004 \\
Land size & $-.286^{* *}$ & .004 \\
Land tenure & $.363^{* *}$ & .000 \\
Forest dependency & $-.363^{* *}$ & .000 \\
\hline
\end{tabular}

To determine the effect of age on the adoption of agroforestry practice, a Spearman's correlation coefficient was calculated to establish the relationship. A positive non-significant correlation $r=0.019, p>0.01$ was arrived at indicating that gender is not a significant predictor of adoption of agroforestry practice. Older farmers are often used as community contact people by initiatives aimed at promoting agroforestry practice. They thus have more access to information on agroforestry. Older people have also accumulated more capital resources and thus have a greater capacity to invest in agroforestry practice. Since they have greater resources endowment, older people can also easily in activities that bring benefits in the long-term such as agroforestry since they have greater access to alternative income sources. In addition, the more a farmer has undertaken production activities in an area, the more experience and knowledge he/she has especially about the local context which means greater prospects for success in agroforestry practice. Similar observations have been made by Nkamleu and Manyong (2005); Lee and Schelhas (1997).

The effect of household size on adoption was also analyzed. In doing this, a Spearman's correlation coefficient was calculated to establish the relationship. A positive correlation $(\mathrm{r}(98)=0.055$, $\mathrm{p}>0.01$ ) that was not significant was arrived at indicating that household size is not a significant predictor of agroforestry practice. Larger households have more labour and hence possess a greater capacity to undertake agroforestry practices. This could especially be more so in households that have a higher proportion of people who can provide labour hence lower dependency ratio. A bigger household size could imply greater adoption of agroforestry practice since it's the individual actions of household members that aggregate into positive impacts. A greater number of household members thus translates into more individual actions as appertains to agroforestry practice hence 
greater adoption levels. These results are confirmed by various studies including Kabende et al. (1990); Adesina and Chianu (2002); Sanchez (1995); WCFSD (1999).

A positive significant correlation $r=0.222, p<0.05$ was found between the effect of formal education on the adoption of agroforestry practice indicating more educated people are better adopters of agroforestry practices. The reason for these results could be due to the more educated people having a higher income, thus greater capital to invest in agroforestry practice. They can also afford to risk more by the adoption of new technologies. The more educated farmer also by having a greater like livelihood or employment opportunities and other alternative sources of income is able to wait for the long-term benefits of agroforestry practice and thus can easily adopt. The more educated people also have a better understanding of management knowledge on agroforestry which leads to better tree performance. They also have higher environmental awareness and thus greater positive perception of agroforestry. Similar findings were also arrived at by Nkamleu and Manyong (2005); Kabende et al., (1990); Attahkrah and Francis 91987) who also found out that education has a significant positive relationship with adoption of agroforestry practice.

The effect of contact with extension service on the adoption of agroforestry practice showed a positive significant correlation coefficient $r=0.393$, $\mathrm{p}<0.01$ ) indicating that more contact with extension service increases adoption of agroforestry practice. The reason for this could be because extension service leads to more access to information and technologies on the adoption of agroforestry practice. There is hence a greater level of adoption for those who have more contact with extension service. Those who have more access to extension service also do have a greater likelihood to participate in demonstration tests. Through the training, they have attained better skills for agroforestry practice. The extension also leads to environmental sensitization, thus greater awareness and hence a more positive perception of the agroforestry practice. This finding was also arrived at by Kuntashula et al. (2002); Nkamleu and Manyong (1995); Alavalapati et al. (1995); Adesina and Chianu (2002).
In determining the effect of membership to community associations and the adoption of agroforestry practice, Spearman's correlation coefficient was calculated to establish the relationship. A positive correlation coefficient $r=$ $0.352, \mathrm{p}<0.01)$ that was significant indicating that greater membership to community associations leads to an increase in the adoption of agroforestry practice. The outcome of this analysis could imply that members to community associations have a greater chance of contacting extension service hence greater likelihood to adopt agroforestry practice. This is because extension services in the community are offered through such group and thus their members have more access. Those who belong to farmers associations could also have more access to knowledge and skills as appertains to the practice of agroforestry through shared learning within and between their groups. Due to this, they may also have more awareness of the positive perception of the practice.

Moreover, those who are members of community associations may be more involved in decision making since farmers these associations are usually the basis for community participation in conservation activities and agroforestry projects. This includes involvement as appertains to problem identification, prioritization and implementation of agroforestry projects. The activities undertaken will, therefore, reflect their circumstances and interests. Their participation will also ensure that the activities undertaken do build on their traditional knowledge and experiences hence boosting their likelihood and capacity to adapt. Similar findings have been arrived at by Adesina and Chianu (2002); Versteeg and Koudokpon (1993); Cavaness and Kurtz (1993); Ajayi et al. (2001); Peterson (1999).

In order to establish the effect of income level on the adoption of agroforestry practice, a Spearman's correlation coefficient was calculated to determine the relationship. A positive correlation coefficient $r$ $=0.289, \mathrm{p}<0.01)$ that was significant was arrived at. This means those people who have higher income adopt agroforestry practice better than those with lower incomes. The finding of this analysis could be explained by the fact that higher-income means the farmer can afford to risk more hence more like likelihood to adopt new technologies. The higher 
income earners also often have more alternative sources of income valves that can allow them to wait for the long-term benefits of agroforestry than those who are poor. They also have more capital to invest in the practice of agroforestry. The higherincome earners could also have more influence in decision making which means the decisions made in agroforestry development initiatives are more likely to address their interests as they participate better hence boosting their morale to undertake proposed activities hence adopt agroforestry practice. This finding agrees with those of Nkamleu and Manyong (2005); Cavaness and Kurtz (1993); Phiri et al. (2003); Peterson (1999); Keil (2000).

The effect of land size on the adoption of agroforestry practice showed a negative significant correlation coefficient $r=-0.286, p<0.01$ ) which means those with bigger land adopt agroforestry practice less than those with smaller land. The reason for this outcome could be that those who have big land face less pressure to adopt since they are more endowed with resources. Those who have smaller pieces of land, however, have to engage in more intensive management practices in order to maximize their benefits and are thus more likely to adopt sustainable land management practices such as agroforestry. The farmers who have smaller land parcels engage in intensive land management to make up for their lack of space. The large land also mainly engage in mechanized farming and thus have to reduce the number of trees on their farms to allow easy movement of their machinery during farm operations as opposed to the small landowners who were found to engage in manual farm operations. Other studies that have arrived at similar results include Adesina and Chianu (2002); Ekisa (2010).

The effect of land tenure on the adoption of agroforestry practice showed a positive correlation coefficient $r=0.363, p<0.01$ ) indicating that better tenure security increases the adoption of agroforestry practice. This outcome could be because those who have more secure land tenure are more certain that they would benefit from the practice of agroforestry on their farms in the longterm. Those who have more secure tenure can thus engage more in long-term investments such as agroforestry since they don't have a high certainty that they will gain from the resulting benefits. This finding is affirmed by Lee and Schelhas (1997); Attahkrah and Francis (1987); Adesina and Chianu (2002); Nkamleu and Manyong (2005).

The correlation between forest dependency and adoption of agroforestry practice showed a negative correlation coefficient $r=-0.363, p<0.01$ ) that was significant meaning that those who depend on forests more are those who have less adoption of agroforestry practice. The results of this analysis can be explained by the fact that agroforestry adoption leads to the planting of trees on the farm that acts as an alternative for tree-based forest products such as firewood. This means that those who have higher adoption have a greater alternative source for forest derived products such as firewood and therefore, will depend less on the forest for these products. Those who however have a low adoption will have a little alternative source for forest derived products and thus will have a high dependence on the forest for these products. This finding is supported by results arrived at by Murniati et al. (2001) who found out that higher forest dependence meant lower levels of agroforestry adoption.

\section{CONCLUSION}

According to the study, the adoption of agroforestry is usually subject to various underlying socioeconomic whose influence is context-specific. Understanding of these factors is key for communities, policymakers and practitioners since it will enable them to make the right planning and management decisions in efforts geared towards promoting adoption and performance of agroforestry practices. This will result in increased adoption and greater success of agroforestry practice leading to increased production, livelihoods diversification and improved livelihoods. Increased adoption of agroforestry practice will reduce dependence and lead to sustainable forest management. Increased adoption of agroforestry adoption will, therefore, reduce encroachment, degradation and deforestation of forest ecosystems 


\section{REFERENCES}

Adesina, A., \& Chianu, J. (2002). Determinants of farmer's adoption and adaptation of alley farming technology in Nigeria, Agroforestry systems, 55, 99 - 112.

Alavalapati, J., Luckert, M., \& Gill, D. (1995). Adoption of agroforestry practices: a case study from Andhra Pradesh India, Agroforestry systems, 32, 1-14.

Anderson, B. (1990). Alternatives to deforestation: steps towards sustainable use of the Amazon Forest. New York, NY: Columbia University Press.

Angelson, A., \& Komiwitze, D. (2001). Is agroforestry likely to reduce forest dependence? Island Press.

Attahkrah, A., \& Francis, P. (1987). The role of onfarm trials in the evaluation of composite technologies: the case study of alley farming in Southern Nigeria, Agricultural systems, 23, 133-152

Ajayi, O. Ayuk, E., Massi, C., Phiri, D., \& Kwesinga, F. (2001). Typology and characteristics of farmers planting improved fallows in Eastern Zambia. Working paper No.

2. Chipata, Zambia: ICRAF.

Batjes, N. (2005). Total carbon and nitrogen in the soils of the world, Soil science, 47, 151-161.

Cavaness, F., \& Kurtz, W. (1993). Agroforestry adoption and farmers perception in Senegal, Agroforestry systems, 21, $11-25$.

Cunningham, M., \& Saigo, B. (1992). Environmental science: a global concern. Dublique: WMC Brown publishers.

Fortmann, L., \& Rocheleau, D. (1984). Why agroforestry needs women: Four myths and a case study. Agroforestry Systems, 2, 253-272.

Huang, W., Lolukkanen, O., Johanson, S., Kaarakka, P., Raisenen, S., \& Vihemaki, H. (2002). Agroforestry for biodiversity conservation of nature reserves: functional group identification and analyses, Agroforestry systems, 55, $65-72$

Kabende, Y., Gunjal, K., \& Coffin, G. (1990). Adoption of new technologies in Ethiopian agriculture: a case study of Tegulet-Bulga district, Shoa province, Agricultural economics, 63(2).

Keil, A. (2001). Improved fallows using leguminous trees in Eastern Zambia; do initial testers accept the technology? Master's thesis. University of Gottingen.

Government of Kenya. (2008). Naivasha district development plan 2008-2012. Government of Kenya

Government of Kenya. (2010). 2009 Kenya population and housing census. Population by administrative units. Government of Kenya

Kenya Forest Research Institute (KEFRI). (2010). Second national communication to the UNFCCC: Climate change mitigation measures and options: Land use, land-use change and forestry.

Kuntashula, E., Ajayi, O., Phiri, D., Mafongoya, P., $\&$ Franzel, S. (2002). Factors affecting farmer's decision to plant improved fallows: a study of four villages in the Eastern province of Zambia, Harare, Zambia.

Kwesinga, F., \& Ajayi, O. (2003). Implications of local policies and institutions on the adoption of improved fallows in Eastern Zambia, Agroforestry systems, 59, 327 - 336.

Lee, D., \& Schelhas, J. (1997). Farmer participation in reforestation incentive programs in Costa Rica, Agroforestry systems, 35.

Mercer, D., \& Miller, R. (1998). Socio-economic research in agroforestry: progress, prospects and priorities, Agroforestry systems, 38, 177 193.

Montagnini, F., \& Nair, P. (2004). Carbon sequestration; an unexploited environmental benefit of agroforestry systems, Agroforestry Systems, 61(1), 281 - 295. 
Murniati, D., Garrity, P., \& Gintings, A. (2001). The contribution of agroforestry to reducing farmer's dependence on the resources of adjacent national parks: a case study from Sumatra Indonesia, Agroforestry systems, 52, $171-184$.

Nair, P. (1989). Agroforestry systems in the tropics. Kluwer, London.

Nasiurma, D. (2000). Survey sampling theory and methods, University of Nairobi Press, Nairobi.

National Museums of Kenya (NMK). (2009). Avifauna survey of Eburru and Sururu Forests in Eastern Mau complex. Nairobi.

Nkamleu, B., \& Manyong, M. (2005). Factors affecting the adoption of agroforestry practices by farmers in Cameroon, Small scale economics, management and policy, 4(2), 135 148.

Peterson, J. (1999). Zambia integrated agroforestry project (ZIAP): baseline survey. Gainesville, Florida: University of Florida,

Phiri, D., Franzel, S., Mafongoya, P., Jere, I., Katanga, R., \& Phiri, S. (2004). Who is using the new technology? The association of wealth status and gender with the planting of improved tree fallows in Eastern Province, Zambia. Agricultural Systems, 79(2), 131-144.

Raiford, W. (1987). Social forestry; an answer to deforestation? Development and cooperation, 4, 15-17.

Schroeder, P. (1999). Shady practices: Agroforestry and gender politics in the Gambia. Berkley: University of California Press.

Versteeg, M., \& Koudokpon, V. (1993). Participative farmer testing of four low input technologies to address soil fertility decline in Mono province, Benin, Agricultural systems, 4(2), 265 - 276. 